\title{
Two New Species of Myrtaceae from Colombia
}

\author{
Carlos Parra-O.
}

Instituto de Ciencias Naturales, Universidad Nacional de Colombia, Carrera 30 \# 45-03, Bogotá, Colombia.caparrao@unal.edu.co

Abstract. Two new species of Myrtaceae are described and illustrated from western tropical humid forests from Valle del Cauca, Colombia. Eugenia calimensis $\mathrm{C}$. Parra-O. is distinguished by leaf shape and densely pubescent inflorescences, and it is somewhat similar to E. chrysophyllum Poir. in the upper surface of the leaf blades and the inflorescence shape. Myrcia icnii C. Parra-O. is affined to $M$. lapidulosa B. Holst \& M. L. Kawas., having similar leaf blades that are elliptic to obovate, coriaceous, and abaxially more or less bullate.

Resumen. Se describen e ilustran dos nuevas especies de Myrtaceae de los bosques húmedos tropicales del occidente del Valle del Cauca, Colombia. Eugenia calimensis C. Parra-O. se caracteriza por la forma de sus hojas, y por sus inflorescencias densamente pubescentes, siendo similar a E. chrysophyllum Poir. por la superficie foliar de la lámina de las hojas, y por el tamaño y la forma de la inflorescencia. Myrcia icnii C. Parra-O. es afín a M. lapidulosa B. Holst \& M. L. Kawas., ya que ambas especies presentan láminas foliares elípticas a obovadas, coriáceas, y más y menos abolladas por el envés.

Key words: Colombia, Eugenia, IUCN Red List, Myrcia, Myrtaceae, Valle del Cauca.

Among Colombian native Myrtaceae, Eugenia L. and Myrcia DC. are the most diverse genera with 41 and 27 species, respectively. Nevertheless, through continuing study of the taxonomy of Colombian Myrtaceae I estimate that undescribed species of Eugenia and Myrcia in Colombia constitute at least half of the number of the species for both genera. Herein I describe new species of Eugenia and Myrcia from Colombia.

1. Eugenia calimensis C. Parra-O., sp. nov. TYPE: Colombia. Valle del Cauca: Bajo Calima, ca. 15 $\mathrm{km} \mathrm{N}$ of Buenaventura, Carton de Colombia concession, $3^{\circ} 56^{\prime} \mathrm{N}, 77^{\circ} 08^{\prime} \mathrm{W}$, ca. $50 \mathrm{~m}, 13$ Feb. 1983 (fl., fr.), A. Gentry, A. Juncosa \& H. Mazuera 40196 (holotype, MO; isotype, COL). Figure 1.
Haec species quoad folia adaxialiter glabra ac inflorescentiam breviter racemosam Eugeniae chrysophyllo Poir. subsimilis, sed ab ea foliis abaxialiter trichomatibus aureobrunneis sparsim modiceve pubescentibus (vs. sericeis) atque fructu globoso (vs. ellipsoideo) distinguitur.

Tree, 10-12 m tall; hairs when present 0.1-0.3 $\mathrm{mm}$, simple, golden-brown; young branches \pm compressed, moderately to densely pubescent; old branches \pm compressed to terete, glabrous to glabrescent. Leaf blades widely elliptic, occasionally elliptic, $14-22.5 \times(6.7) 8.2-14.8 \mathrm{~cm}$, coriaceous, upper surface generally glabrous, occasionally glabrescent, with impressed and almost imperceptible glandular dots, lower surface sparsely to moderately pubescent, with raised brownish orange glands, apex apiculate, apiculum 2.8-7.2 $\mathrm{mm}$, base subcordate, sometimes obtuse, blade margin moderately to markedly revolute; midvein slightly convex above, glabrous to moderately pubescent, convex below, moderately to densely pubescent; lateral veins in 10 to 13 pairs, convex on both blade surfaces, glabrescent to moderately pubescent, venation joining in an inframarginal vein at $1-2.9 \mathrm{~mm}$ from margin; petiole 9-12 mm, reddish or blackish brown, rugose, moderate to densely pubescent, terete. Inflorescence axillary, briefly racemose, $0.7-1 \mathrm{~cm}$, solitary ( 2 or 3 ) at the nodes, with 4 to 7 flowers per raceme, fertile axes rectangular or compressed, densely pubescent, brown to golden-brown; peduncles $0.4-0.7 \times 0.8-1 \mathrm{~mm}$; bracts widely ovate, $0.5-1$ $\times 0.6-1 \mathrm{~mm}$, glabrescent to moderately pubescent, basally truncate, persistent; bracteoles 2, opposite at base of hypanthium, connate at base, widely ovate, $0.8-0.9 \times 0.9-1.2 \mathrm{~mm}$, glabrescent to moderately pubescent (especially pubescent at margin and apex), persistent after anthesis. Flowers with buds obovoid or globose, $2-2.9 \times 2-2.5 \mathrm{~mm}$, moderately pubescent, on \pm compressed pedicels, 4.8-7 $\times 0.5-0.6$ $\mathrm{mm}$, densely pubescent; sepal lobes 4 , in unequal pairs, outer pair widely triangular, 1.1-1.5 $\times 0.8-1.6$ $\mathrm{mm}$, inner pair widely ovate, $1.2-1.4 \times 1.6-1.8 \mathrm{~mm}$, both glabrescent to sparsely pubescent outside, glabrous inside, apex obtuse or subobtuse; petals 4 , white, obovate or widely elliptic, 2.9-3.4 × 2.1-2.4 $\mathrm{mm}$, glabrous except for ciliate margin, apex obtuse, base truncate; stamens forty to sixty, 2.1-3.6 mm; 


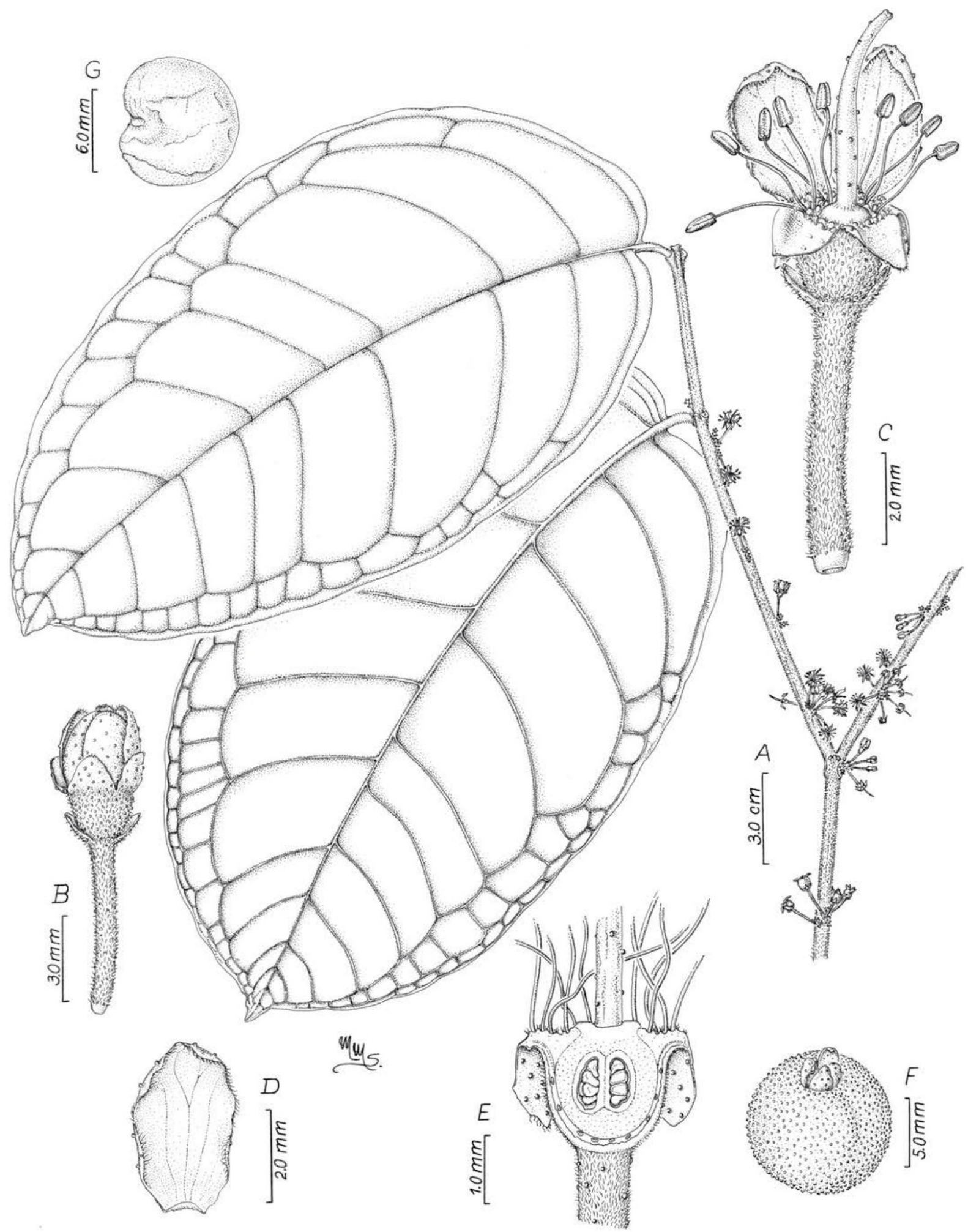

Figure 1. Eugenia calimensis C. Parra-O. - A. Flowering branch. - B. Flower bud. -C. Flower after anthesis, with two petals and most of the stamens removed. - D. Petal, with ciliate margin. - E. Longitudinal section of hypanthium and ovary. -F. Fruit. - G. Seed. A, C-E are drawn from the holotype, Gentry et al. 40196 (MO); B, F, G drawn from the isotype, Gentry et al. 40196 (COL).

filaments 1.6-3.1 mm, anthers ellipsoid, $0.5 \mathrm{~mm}$, bearing 1 apical gland; hypanthium $1.6-1.8 \mathrm{~mm}$ diam., not prolonged above the ovary, moderately to densely pubescent outside, glabrous inside; disk 1.9-
$2.1 \mathrm{~mm}$ diam., moderately pubescent; ovary $1-1.1$ mm diam., 2-locular, 6 to 11 ovules per locule, style $3.7-4.3 \mathrm{~mm}$, glabrous. Fruits globose, red or blackish, 7.9-8.7 $\mathrm{mm}$ diam., exocarp glabrous to 
glabrescent; seeds 1 per fruit, slightly reniform, $8.7 \times$ ca. $8 \mathrm{~mm}$, seed coat papyraceous, brownish yellow, smooth, with blackish glands; embryo eugenioid.

Habitat and etymology. The specific epithet of the new species refers to the Bajo Calima region, which is located in the western tropical humid forests in the department of Valle del Cauca, at elevations between 0 and $150 \mathrm{~m}$. The forests of this region are considered among the most species rich in the world (Faber-Langendoen \& Gentry, 1991), and several new species of angiosperms have been described, some of which are endemic to the western tropical humid forests (e.g., Wasshausen, 1989; LozanoContreras, 1994; Taylor et al., 1999; Croat et al., 2007; Ricketson \& Pipoly, 2008).

IUCN Red List category. As this new species is only known from one location, and no other collections have been found, the conservation status of Eugenia calimensis can only be assessed as Data Deficient, or DD, according to IUCN Red List criteria (IUCN, 2001).

Discussion. Eugenia calimensis is a distinctive species among Colombian Eugenia and is recognized by its widely elliptic, apiculate, coriaceous leaves, by the briefly racemose, densely pubescent inflorescences only to $1 \mathrm{~cm}$ long, and by the small flower buds no more than $2.9 \mathrm{~mm}$ in length. Eugenia calimensis is somewhat similar to E. chrysophyllum Poir., a species known from Panama, Colombia, Peru, and Brazil and from Venezuela to French Guiana. The upper surface of leave blades on both species is glabrous, and their inflorescences are similar in shape. Eugenia calimensis differs from E. chrysophyllum by the pubescence of the lower surface of leaf blade (sparsely to moderately pubescent with golden-brown hairs vs. sericeous) and by its fruit shape (globose vs. ellipsoid).

Paratype. COLOMBIA. Valle del Cauca: Bajo Calima, ca. $15 \mathrm{~km} \mathrm{~N}$ of Buenaventura, Carton de Colombia concession, $3^{\circ} 56^{\prime} \mathrm{N}, 77^{\circ} 08^{\prime} \mathrm{W}$, ca. $50 \mathrm{~m}, 16 \mathrm{Feb} .1983$ (bud, fr.), A. Gentry, A. Juncosa, H. Mazuera \& W. Ladrach 40357 (COL, MO).

2. Myreia ienii C. Parra-O., sp. nov. TYPE: Colombia. Valle del Cauca: Bajo Calima, Concesión Pulpapel/Buenaventura, $3^{\circ} 55^{\prime} \mathrm{N}$, $77^{\circ} \mathrm{W}$, ca. $100 \mathrm{~m}, 3$ Aug. 1984 (fl., fr.), $M$. Monsalve 163 (holotype, CUVC; isotype, MO). Figure 2.

Haec species quoad folia coriacea elliptica obovatave abaxialiter bullata Myrciae lapidulosae B. Holst \& M. L. Kawas ut videtur affinis, sed ab ea foliis majoribus (26-33 $\times 13.5-20 \mathrm{~cm}$ vs. $8-16.5 \times 3.5-11 \mathrm{~cm})$, panicula plerumque longiore ([7] $18-24 \mathrm{~cm}$ vs. $5-10 \mathrm{~cm}$ ), petalis brevioribus (2.4-2.9 $\mathrm{mm}$ vs. ca. $7 \mathrm{~mm})$, fructu minore $(0.9-$ $1.2 \mathrm{~cm}$ vs. ca. $2.2 \mathrm{~cm}$ ) atque seminibus minoribus (5.6-7 $\mathrm{mm}$ vs. ca. $15 \mathrm{~mm}$ ) distinguitur.

Tree, 5-6 m tall; hairs when present $0.1-0.5(0.7)$ $\mathrm{mm}$, simple, light golden; young branches flattened to \pm compressed, moderately to densely pubescent; old branches \pm compressed to terete, glabrous to glabrescent. Leaf blades elliptic or obovate, 26-33 $\times 13.5-20 \mathrm{~cm}$, coriaceous, upper surface glabrous, with impressed glandular dots, lower surface glabrescent to slightly pubescent, slightly bullate, with raised brownish orange glands, apex apiculate, apiculum 7.3-10 mm, base cuneate, margin entire; midvein above flat to slightly convex (at least in distal $2 / 3$ ), slightly convex to convex to apex, generally glabrous (occasionally glabrescent), strongly convex below, moderately to densely pubescent; lateral veins in 21 to 24 pairs, flat above, glabrous, convex below, moderately to densely pubescent, marginal veins 2 , inner one $2.7-4 \mathrm{~mm}$ from margin, outer one $0.5-1$ $\mathrm{mm}$ from margin, sometimes almost imperceptible; petiole $8-13 \mathrm{~mm}$ long, dark brown, slightly rugose, moderately to densely pubescent, canaliculate. Inflorescence subterminal, paniculate, (7) $18-24 \mathrm{~cm}$, with 40 to 60 flowers per panicle, axes compressed, densely pubescent, brown to purple-brown; peduncles $60 \times 3-3.7 \mathrm{~mm}$; bracts unknown; bracteoles unknown. Flower buds unknown; flowers sessile; sepal lobes 5 , widely triangular to depressed ovate, $1.7-1.9 \times 2.6-3.3 \mathrm{~mm}$, moderately pubescent both outside and inside, with brownish orange glands, apex obtuse to \pm obtuse; petals 4 , obovate or widely elliptic, $2.4-2.9 \times 2.3-2.6 \mathrm{~mm}$, dorsally glabrescent, ventrally moderately to densely pubescent, apex obtuse to \pm obtuse, base truncate to cuneate; stamens seventy to ninety, $2.6-4.3 \mathrm{~mm}$; filaments 2.3-4 mm, anthers globose, $0.3 \mathrm{~mm}$, without apical glands; hypanthium 1.9-2.3 mm diam., not prolonged above ovary, moderately to densely pubescent both outside and inside; disk $3.6 \mathrm{~mm}$ diam., densely pubescent; style $5.2 \mathrm{~mm}$, moderately pubescent at base, glabrescent from middle to apex; ovary $1.8 \mathrm{~mm}$ diam., 2-locular, 1 or 2 ovules per locule; style 5.2 $\mathrm{mm}$, moderately pubescent at base, glabrescent from middle to apex. Fruits ellipsoid, red, 0.9-1.2 cm, exocarp moderately pubescent; seeds developing as 1 per fruit, slightly reniform, $5.6-7 \times 3.5-4.3 \mathrm{~mm}$, seed coat papyraceous, brownish orange, smooth, with immersed glands; embryo myrcioid.

IUCN Red List category. Because this new species is only known from one location, and no 


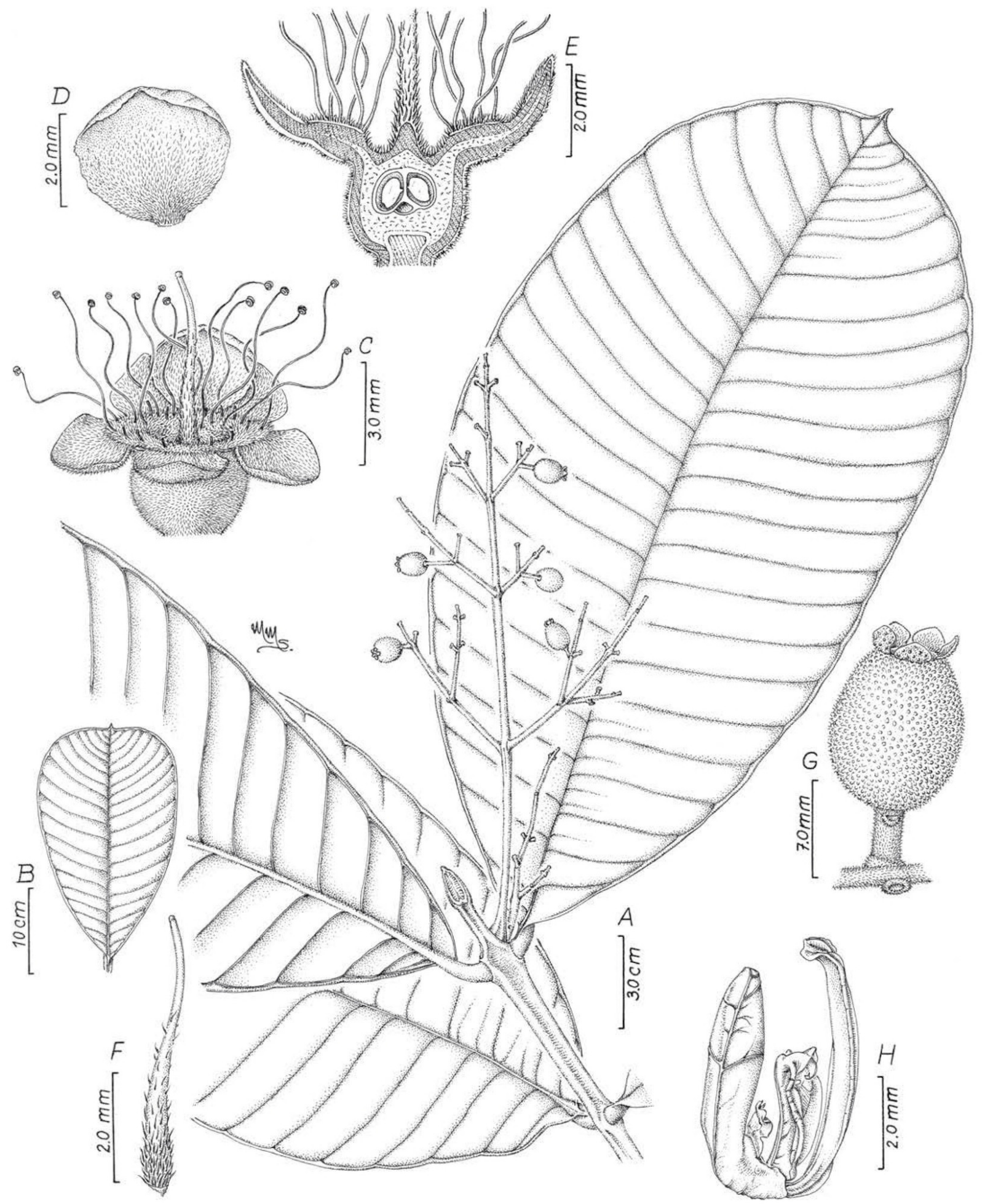

Figure 2. Myrcia icnii C. Parra-O. - A. Fruiting branch, with elliptic leaves. - B. General view of one leaf, showing shape variation as an obovate leaf blade. - C. Flower after anthesis, with some sepals, most of the petals, and most of the stamens removed. - D. Petal, showing pubescence and more or less obtuse apex. - E. Longitudinal section of hypanthium and ovary, showing the single ovule per locule. - F. Detail of style, with moderate pubescence basally. - G. Fruit, with persistent calyx and immersed glands visible. - H. Myrcioid embryo. A, C-F are drawn from the holotype, M. Monsalve 163 (CUVC); B from I. Cabrera et al. 15606 (CUVC); G and $\mathrm{H}$ from the isotype, M. Monsalve 163 (MO).

other collections have been found, the conservation status of Myrcia icnii can only be assessed as Data Deficient, or DD, according to IUCN Red List criteria (IUCN, 2001).
Etymology. Myrcia icnii is named to honor the Instituto de Ciencias Naturales (ICN), my home institution at the Universidad Nacional de Colombia, which has been a leader in research in taxonomy and 
systematics of Colombian flora and fauna for more than 75 years. The epithet choice as an arbitrary noun is supported by Article 23.2 of the International Code of Nomenclature for algae, fungi, and plants (Melbourne Code; McNeill et al., 2012).

Discussion. Myrcia icnii seems to be related to $M$. lapidulosa B. Holst \& M. L. Kawas., a species from Panama. The leaves of the species are similar in shape (elliptic or obovate blades), thickness (coriaceous), and texture of the blade surface (slightly bullate to bullate on the lower surface). Nevertheless, M. icnii differs from $M$. lapidulosa by the size of its larger leaves $(26-33 \times 13.5-20 \mathrm{~cm}$ vs. 8-16.5 × 3.5$11 \mathrm{~cm}$ in M. lapidulosa), by its shorter petals (2.4-2.9 $\mathrm{mm}$ vs. ca. $7 \mathrm{~mm}$ ), its typically longer panicles ([7]18-24 cm vs. 5-10 cm), its smaller fruits (0.9-1.2 cm vs. ca. $2.2 \mathrm{~cm})$, and its smaller seeds $(5.6-7 \mathrm{~mm}$ vs. ca. $15 \mathrm{~mm})$.

Paratype. COLOMBIA. Valle del Cauca: Bajo Calima, 50 m, 8 July 1987 (st.), I. Cabrera et al. 15606 (CUVC).

Acknowledgments. I am grateful to CUVC and MO for providing access to their collections. Thanks are expressed to Marcela Morales, who prepared the illustrations. M. L. Kawasaki and Marcos Sobral made helpful comments on the manuscript. I also thank Rosa Ortiz-Gentry (MO) for providing images of selected specimens of Colombian Myrtaceae deposited at MO. As well, I thank the Herbario Nacional Colombiano (COL), and particularly the Instituto de
Ciencias Naturales, at the Universidad Nacional de Colombia for their support.

\section{Literature Cited}

Croat, T., D. Bay \& E. Yates. 2007. New species of Stenospermation and Xanthosoma (Araceae) from Bajo Calima, Valle Department, Colombia. Novon 17: 298305.

Faber-Langendoen, D. \& A. Gentry. 1991. The structure and diversity of rain forests at Bajo Calima, Chocó Region, Western Colombia. Biotropica 23(1): 2-11.

IUCN. 2001. IUCN Red List Categories and Criteria, Version 3.1. Prepared by the IUCN Species Survival Commission. IUCN, Gland, Switzerland, and Cambridge, United Kingdom. <http://www.iucnredlist.org>, accessed 2 July 2014.

Lozano-Contreras, G. 1994. Dugandiodendron y Talauma (Magnoliaceae) en el Neotrópico. Academia Colombiana de Ciencias Exactas, Físicas y Naturales. Colecc. Jorge Álvarez Lleras 3: 1-147.

McNeill, J., F. R. Barrie, W. R. Buck, V. Demoulin, W. Greuter, D. L. Hawksworth, P. S. Herendeen, S. Knapp, K. Marhold, J. Prado, W. F. Prud'homme van Reine, G. F. Smith, J. H. Wiersema \& N. J. Turland (editors). 2012. International Code of Nomenclature for algae, fungi, and plants (Melbourne Code). Regnum Veg. 154.

Ricketson, J. \& J. Pipoly. 2008. A new species of Parathesis (Myrsinaceae) from Colombia. Novon 18: 241-243.

Taylor, C., W. Devia, A. Cogollo \& C. Persson. 1999. Nuevos taxones de Rubiaceae de la Costa Pacífica de Colombia y Ecuador. Novon 9: 431-440.

Wasshausen, D. 1989. New and interesting species of Acanthaceae from Colombia. Revista Acad. Colomb. Ci. Exact. 17(65): 249-257. 


\section{$2 \mathrm{BHL}$ Biodiversity Heritage Library}

Parra-O., Carlos. 2015. "Two New Species of Myrtaceae from Colombia." Novon a journal of botanical nomenclature from the Missouri Botanical Garden 23(4), 437-441. https://doi.org/10.3417/2012072.

View This Item Online: https://www.biodiversitylibrary.org/item/218333

DOI: https://doi.org/10.3417/2012072

Permalink: https://www.biodiversitylibrary.org/partpdf/218598

\section{Holding Institution}

Missouri Botanical Garden, Peter H. Raven Library

\section{Sponsored by}

Missouri Botanical Garden

\section{Copyright \& Reuse}

Copyright Status: Permission to digitize granted by rights holder Rights: https://www.biodiversitylibrary.org/permissions

This document was created from content at the Biodiversity Heritage Library, the world's largest open access digital library for biodiversity literature and archives. Visit BHL at https://www.biodiversitylibrary.org. 